\title{
Women Traders Livelihoods in Tourism Area of Lok Baintan Floating Market
}

\author{
Deasy Arisanty ${ }^{1}$, Herry Porda Nugroho Putro ${ }^{2}$, Ellyn Normelani ${ }^{1}$, Moh. Zaenal Arifin Anis ${ }^{3}$ \\ ${ }^{1}$ Department of Geography Education, Faculty of Teacher Training and Education, Lambung Mangkurat University, \\ Banjarmasin, Indonesia \\ ${ }^{2}$ Master of Social Science Education, Faculty of Teacher Training and Education, Lambung Mangkurat University, \\ Banjarmasin, Indonesia \\ ${ }^{3}$ Department of History Education, Faculty of Teacher Training and Education, Lambung Mangkurat University, \\ Banjarmasin, Indonesia
}

\begin{abstract}
The destination of tourism in South Kalimantan Province was Lok Baintan Floating Market. Lok Baintan Floating Market was an icon of Banjar cultural tourism. The objective of this research was to analyze the livelihoods of women traders in Lok Baintan Floating Market as a tourism area. It was also to analyze the influential factor of women trader livelihood in the Lok Baintan Floating Market. Data collection used survey methods and questionnaires. The number of Women traders was 50 people. The analysis used was by calcifying index values and factor tests. Livelihood index values determined the level of livelihood of women traders. Factor tests determined the factors that most influence for livelihood level of women traders. The results showed that the livelihoods of Women traders were in the moderate category. It means that natural resource assets, financial assets, human resource assets, physical assets, social assets, access, and activities were still able to support women's lives in tourist areas. Physical assets had the highest value of the Sustainable Livelihood Approach (SLA), which was 73.33\%. Financial assets had the lowest value of SLA, whichwas $50.00 \%$. The influences of factor 1 and factor 2 were $62.778 \%$ for women trader livelihoods. Factors in group 1 were natural resource assets, financial assets, and human assets. The second factors were physic assets, activity and social assets.
\end{abstract}

Keywords: livelihood, sustainable, tourism, women trader.

\section{INTRODUCTION}

Lok Baintan Floating Market is a mainstay tourist attraction in South Kalimantan, Indonesia. Trading activities as a tourist attraction in the area are unique because they use traditional boats called jukung. Another unique thing is that the tourism activities in Lok Baintan dominated by women [1-3].

Trading activities at Lok Baintan Floating Market start in the morning. Merchandise traded at Lok Baintan Floating Market is the product of plantations and fisheries. Merchandise is obtained from the results of the plantation and fisheries themselves or other residents in the tourist area. Tourism and agricultural activities are a source of sustainable livelihood in the Lok Baintan Floating Market [1-3]. Tourism activities have a major impact on sustainable livelihoods for indigenous people. The development of rural tourism has an impact on sustainable livelihoods and reducing poverty in the village [4-5].

Increasing community welfare is obtained by utilizing the potential natural resources in an

\footnotetext{
* Corespondence Address:

Deasy Arisanty

E-mail : deasyarisanty@ulm.ac.id

Address : Lambung Mangkurat University, Jl. Brigjen H. Hasan Basri, Banjarmasin, 70123
}

area. One of the potential natural resources to improve people's lives is tourism activities. Tourism activities have played a very important role in improving people's livelihoods. Expenditures incurred by tourists are a source of income for local people [6]. Trading activities in tourist areas have an important impact on the welfare of traders in Lok Baintan. Plantation and fishery products sold in tourist areas have become a source of income for the community [2].

Tourism activities can indirectly help the economy of the community; trigger the emergence of new businesses and the development of community resources (HR) [7]. The concept of sustainable tourism as an approach was expected to build the economy of the community with the support of tourism activities. Sustainable tourism causes environmental impacts, besides helping residents in tourist areas to earn income and to create jobs [8]. Sustainable livelihood tourism is tourism activities that can overcome vulnerabilities and achieve sustainable economic, social, environmental, and sustainable institutional outcomes [9]. Sustainable Livelihood Approach (SLA) consists of human capital, natural capital, financial capital, physical capital, and social capital [10]. 
Tourism activities have provided many opportunities for women to improve their lives, especially in developing countries. Flexibility in tourism activities causes women to continue their traditions while increasing their living standards [11]. The effectiveness of tourism activities as a tool for poverty alleviation depends on management strategies in maximizing positive impacts and minimizing negative impacts on households [12]. Tourism activities in Lok Baintan are very beneficial for women. Women in Lok Baintan can have a dual role both as traders and as farmers and fish collectors and can still play a role as mothers in their families [1].

The development of tourism activities has an impact on changes in people's lives in Lok Baintan Village. There are many opportunities that people can use to support their economy to make it better. The livelihood framework approach was chosen to assess these changes from various sides and not only focus on one side [13]. Livelihood includes tangible assets and tangible resources and assets, such as claims and access [14]. Livelihood can also consist of capabilities, assets (including material and social resources), and activities needed for living facilities. A sustainable livelihood can occur if it can recover from pressure and shock, maintain or enhance its capabilities and assets, while not damaging the natural resource base [13]. Based on exposure to the background, the objective of the research was to analyze the livelihoods of women traders in Lok Baintan Floating Market as a tourism area and to analyze the influence factor of women trader livelihood in the Lok Baintan Floating Market.

\section{MATERIALS AND METHOD \\ Data Collection}

The number of traders on the Lok Baintan Floating Market is about 100 people, that traders dominated by women [15]. The sampling technique is purposive sampling. The samples are women traders. Samples of research are 50 of women traders.

The variables used based on Pentagon assets are human capital, social capital, natural capital, physical capital, and financial capital [13]. Livelihoods can also be approved based on claims and access [14]. Livelihood is the ability of individuals or households consisting of assets (natural, physical, human, financial, and social capital), activities, and access mediated by institutions and social relations that are jointly linked [16].
Human assets consist of skill, knowledge, ability to work, and good health. Nature assets consist of land, water, forest, and livestock. The financial asset consists of cash, deposit, or reserves in the form of livestock, jewelry, and regular income consisting of salaries, pensions, or transfers. Physical assets consist of the presence of transportation, irrigation, energy, and information media. Social assets are related to the way people connect and work together in the community [17]. The number of questions is 54 questions. The variable and indicators are presented in Table 1.

\section{Livelihood Level Measurement}

Livelihood level measurement is done by giving a score to each indicator, and then the scores of all indicators added based on the answers per person (respondent). Next is coding, an activity of giving numerical codes (numbers) to data consisting of several categories. Scoring is giving an assessment of items that need to be given an assessment or score. Tabulating is the answers that are coded and then entered into the table.

\section{Data Analysis}

The next is data processing to analyze the level of sustainable livelihood by grouping the results of the questionnaire by calculating the percentage of respondents' answers to each research variable and indicator. The index value classified into three types, namely low, medium, and high. Table 2 describes the categories of scoring for each variable.

The factors that influence the level of livelihood of the community are analyzed using factor tests of the Principal Component Analysis (PCA) method. PCA is a statistical analysis used to analyze patterns in data, differences, and similarities of the data [18]. The PCA method aims to simplify the variables observed by reducing its dimensions. It is done in a way that eliminates the correlation between independent variables through the transformation of the free variable origin to the new variable, which is not correlated at all. After several components of the PCA results that are free of multicollinearity obtained, then the components become independent variables, new ones that will be regressed or analyzed for their effects on not free $(Y)$ variables using regression analysis. The excellence of PCA variables includes being able to eliminate correlations cleanly without having to pass a variable number of desires [19]. Analysis of factor test uses the SPSS 22 application. 
Women Traders Livelihoods in Lok Baintan Floating Market

(Arisanty, et al.)

Table 1. Research Variable and indicators

\begin{tabular}{|c|c|}
\hline Variable & Indicator \\
\hline \multirow{6}{*}{ Natural resources assets } & Water resources \\
\hline & Land Ownership \\
\hline & Ownership of paddy field \\
\hline & Ownership of plantation \\
\hline & Ownership of ponds \\
\hline & Ownership of Livestock \\
\hline \multirow{9}{*}{ \Financial assets } & Regular income \\
\hline & Side income \\
\hline & Ownership of Business \\
\hline & Ownership of gold \\
\hline & Ownership of saving \\
\hline & Ownership of Insurance \\
\hline & Ownership of accounts receivable \\
\hline & Ownership of regular social gathering money \\
\hline & Ownership of credits \\
\hline \multirow{9}{*}{ Human resources assets } & Education level \\
\hline & Funds for education \\
\hline & Expertise other than trading in Lok Baintan \\
\hline & Current employment status \\
\hline & Involvement of family members at work \\
\hline & Frequency of disease \\
\hline & Involvement in immunization programs \\
\hline & Involvement in family planning programs \\
\hline & Sponsor's health \\
\hline \multirow{5}{*}{ Social assets } & Mutual cooperation activities \\
\hline & Community organization \\
\hline & Organizational management \\
\hline & Family ownership in residence \\
\hline & Relations with the government \\
\hline \multirow{6}{*}{ Physical assets } & Source of drinking water \\
\hline & Residence ownership \\
\hline & Motorcycle ownership \\
\hline & Toilet ownership \\
\hline & Electricity ownership \\
\hline & Information technology ownership \\
\hline \multirow{8}{*}{ Access } & Access to roads \\
\hline & Access to information technology services \\
\hline & Access to markets \\
\hline & Access to health \\
\hline & Access to education services \\
\hline & Access to banking services \\
\hline & Access to communication services \\
\hline & Access to government services \\
\hline \multirow{10}{*}{ Activities } & Plantation activities to support tourism activities \\
\hline & Farm activities to support tourism activities \\
\hline & Livestock activities to support tourism activities \\
\hline & Fishing activities to support tourism activities \\
\hline & Business service activities \\
\hline & Frequency of eating \\
\hline & Frequency of service to the market \\
\hline & Frequency of services to health \\
\hline & Frequency of services to education \\
\hline & Frequency of services to banks \\
\hline
\end{tabular}


Table 2. Scoring Category

\begin{tabular}{lcccc}
\hline \multirow{2}{*}{ Variable } & \multirow{2}{*}{ Number of question } & \multicolumn{2}{c}{ Category } \\
\cline { 3 - 5 } & & Low & Medium & High \\
\hline Natural resources assets & 6 & $6-9$ & $10-13$ & $14-18$ \\
Financial assets & 9 & $9-14$ & $15-20$ & $21-27$ \\
Human resources assets & 9 & $9-14$ & $15-20$ & $21-27$ \\
Social assets & 5 & $5-8$ & $9-12$ & $13-15$ \\
Physical assets & 7 & $7-11$ & $12-16$ & $17-21$ \\
Access & 8 & $8-13$ & $14-19$ & $20-24$ \\
Activities & 10 & $10-16$ & $17-23$ & $24-30$ \\
Livelihood & 54 & $54-89$ & $90-125$ & $126-162$ \\
\hline
\end{tabular}

\section{RESULT AND DISCUSSION}

\section{Natural Resource Assets}

The natural resource index value is determined based on ownership of agricultural land, livestock, and fisheries. Based on Table 3, $52 \%$ of the natural resources in the Lok Baintan Village are still able to support the survival of women merchant households. Most of the women traders in the Lok Baintan Floating Market tourist area have their own land to be managed as plantation land in the form of oranges, pineapples, and bananas. Lok Baintan Village also has rice fields, but not all traders have their own rice fields, yet they can work on other people's fields with a profit-sharing system. Ponds and livestock only owned by a small proportion of Women traders because the respondents are more of respondents who use gardens and rice fields. The existence of a floating market makes it very easy to sell their agricultural products.

Table 3. Natural Resource Assets Index Value

\begin{tabular}{lcccc}
\hline \multirow{2}{*}{ Natural } & \multicolumn{4}{c}{ Criteria } \\
\cline { 2 - 5 } Resource Assets & Low & Medium & High & \multirow{2}{*}{ Total } \\
& $\mathbf{6 - 9}$ & $\mathbf{1 0 - 1 3}$ & $\mathbf{1 4 - 1 8}$ & \\
\hline Total & 19 & 26 & 5 & 50 \\
Percentage (\%) & 38 & 52 & 10 & 100 \\
\hline
\end{tabular}

\section{Financial Assets}

Financial capital is an economic asset that shows the mastery of financial facilitation in terms of community income. The financial assets in Table 4 classified as a medium with a percentage of $50 \%$ and $50 \%$ are classified low, which means they are still able to support the livelihoods of people in their daily lives. The regular income of Women traders, the majority of whom earn > IDR 600,000 /month, is obtained from the sale of garden products or fish in the Lok Baintan floating market. Floating market activities have been able to facilitate them in earning income. The results they obtained from tourism, agriculture, and fisheries activities turned out to have made traders able to fulfill their daily needs. Even though they could not afford to buy gold and save, they also did not have receivables, and did not have credit goods.

Table 4. Financial Asset Index Value

\begin{tabular}{lcccc}
\hline \multirow{2}{*}{ Financial Assets } & \multicolumn{4}{c}{ Criteria } \\
\cline { 2 - 5 } & Low & Medium & High & Total \\
& $\mathbf{9 - 1 4}$ & $\mathbf{1 5 - 2 0}$ & $\mathbf{2 1 - 2 7}$ & \\
\hline Total & 25 & 25 & 0 & 50 \\
Percentage (\%) & 50 & 50 & 0 & 100 \\
\hline
\end{tabular}

Human Resources Assets

Human resources are one of the drivers of the household economy. Knowledge and capabilities possessed by humans are needed to manage other livelihood assets. The human resource assets in Table 5 classified as moderate, with a percentage of $62 \%$, which means they are still able to support the lives of everyday citizens. The average education of women traders in the floating market is dominated by low education. But some reach the level of junior secondary school and undergraduate/diploma. Even though they are not highly educated, traders have a desire that their children have higher education.

Table 5. Asset Value Index of Human Resources

\begin{tabular}{lcccc}
\hline \multirow{2}{*}{$\begin{array}{c}\text { Human resources } \\
\text { assets }\end{array}$} & Low & Medium & High & \multirow{2}{*}{ Criteria } \\
\cline { 2 - 5 } & $\mathbf{9 - 1 4}$ & $\mathbf{1 5 - 2 0}$ & $\mathbf{2 1 - 2 7}$ & \\
\hline Total & 5 & 31 & 14 & 50 \\
Percentage (\%) & 10 & 62 & 28 & 100 \\
\hline
\end{tabular}

The education costs taken are self-financing from the results they trade in a floating market. Traders do not have any expertise other than trading and farming. Women traders also tend to involve family members to help them trade. The form of assistance is harvesting plantation products and catching fish for resale in floating markets. The adequate health facilities in the Lok Baintan area provide easy access to health for the traders. They rarely get diseases, and if they are sick, they immediately seek treatment at a community health center available in their village. Women traders also easily get their reproductive health facilities through family planning programs. 


\section{Social Assets}

Social capital is an illustration of the ease in social networks that is used by both formal and informal households that are the foundation for survival. The social assets in Table 6 are classified as low, with a percentage of $50 \%$, meaning that the social assets have not been able to support the livelihood of Women traders in Lok Baintan. Mutual cooperation activities are only carried out temporarily by residents, which is only done if there are certain tourism events. Women traders at Lok Baintan are not involved in tourism organizations and are not administrators in tourism organizations. Women are also not involved in decision-making related to tourism activities. Women are only tourism agents, not as policymakers in tourism activities.

Table 6. Social Asset Index Value

\begin{tabular}{ccccc}
\hline \multirow{2}{*}{ Social Assets } & \multicolumn{4}{c}{ Criteria } \\
\cline { 2 - 5 } & Low & Medium & High & \multirow{2}{*}{ Total } \\
& $\mathbf{5 - 8}$ & $\mathbf{9 - 1 2}$ & $\mathbf{1 3 - 1 5}$ & \\
\hline Total & 25 & 20 & 5 & 50 \\
Percentage (\%) & 50 & 40 & 10 & 100 \\
\hline
\end{tabular}

\section{Physical Assets}

Physical resources are basic infrastructure and other facilities built to support the community's sustainable livelihood processes. Access assets classified as moderate, with a percentage of $76 \%$ (Table 7). It means that physical assets are still able to support the livelihoods of everyday people. Physical resources, such as roads, clean water resources, electricity, home-ownership, ownership of motorbikes, toilets, and communication facilities, have been able to support the lives of women traders in the Lok Baintan tourist area. Generally, traders have physical assets that they use in their daily lives and used in tourism activities. The disadvantage is the quality of physical access, for example, poor houses and the condition of toilets built on the banks of rivers. The latrine that was built on the edge of the river is less feasible in a tourist area.

Table 7. Physical Asset Index Value

\begin{tabular}{lcccc}
\hline \multirow{2}{*}{ Physical Assets } & \multicolumn{4}{c}{ Criteria } \\
\cline { 2 - 5 } & Low & Medium & High & \multirow{2}{*}{ Total } \\
& $\mathbf{7 - 1 1}$ & $\mathbf{1 2 - 1 6}$ & $\mathbf{1 7 - 2 1}$ & \\
\hline Total & 1 & 38 & 11 & 50 \\
Percentage (\%) & 2 & 76 & 22 & 100 \\
\hline
\end{tabular}

\section{Access}

Access assets are infrastructure built in the village to support the improvement of community livelihoods. Access assets in Table 8, classified as high with a percentage of $96 \%$, which means they are capable of supporting the improvement of people's livelihoods. Access to communication, market, education, and health services is very easy to reach by citizens. Access that is still difficult to reach by citizens is bank access. The bank is located far from the Lok Baintan. Markets, educational facilities, and health facilities are available in the village. Women traders are easy to access these facilities because they are available in the tourist village.

Table 8. Access Index Value

\begin{tabular}{lcccc}
\hline \multirow{2}{*}{ Access } & \multicolumn{4}{c}{ Criteria } \\
\cline { 2 - 5 } & Low & Medium & High & Total \\
& $\mathbf{8 - 1 3}$ & $\mathbf{1 4 - 1 9}$ & $\mathbf{2 0 - 2 4}$ & \\
\hline Total & 0 & 2 & 48 & 50 \\
Percentage (\%) & 0 & 4 & 96 & 100 \\
\hline
\end{tabular}

\section{Activity}

Activities here mean community activities to support daily livelihoods. The activity in Table 9 classified as a medium with a percentage of $90 \%$, which means that it can support the improvement of people's livelihoods. Women's activities in the tourist area in Lok Baintan, besides being traders, are becoming farmers. Tourism and agricultural activities have sustained women's lives in the tourist area. The frequency of services has been able to support the lives of women traders. Women traders have received regular frequency of market, health, and education services. The frequency of services that are still not regular is banking.

Table 9. Activity Index Value

\begin{tabular}{lcccc}
\hline \multirow{2}{*}{ Activity } & \multicolumn{4}{c}{ Criteria } \\
\cline { 2 - 5 } & Low & Medium & High & \multirow{2}{*}{ Total } \\
& $\mathbf{1 0 - 1 6}$ & $\mathbf{1 7 - 2 3}$ & $\mathbf{2 4 - 3 0}$ & \\
\hline Total & 4 & 45 & 1 & 50 \\
Percentage (\%) & 8 & 90 & 2 & 100 \\
\hline
\end{tabular}

Women's Trader Livelihoods

The livelihood index values of traders in the Lok Baintan Floating Market shown in Table 10. The level of livelihood of female traders in Lok Baintan Village in Table 10 shows that the index value is in the medium category, with a percentage of $96 \%$. Natural resources, financial, human resources, social, physical, accessibility, access, and activity can be able to support the livelihood of women traders in the Lok Baintan Floating Market area.

Table 10. Value of Female Traders Livelihoods Index

\begin{tabular}{lcccc}
\hline \multirow{2}{*}{ Livelihood } & \multicolumn{4}{c}{ Criteria } \\
\cline { 2 - 5 } & Low & Medium & High & Total \\
& $\mathbf{5 4 - 8 9}$ & $\mathbf{9 0 - 1 2 5}$ & $\mathbf{1 2 6 - 1 6 2}$ & \\
\hline Total & 0 & 48 & 2 & 50 \\
Percentage (\%) & 0 & 96 & 4 & 100 \\
\hline
\end{tabular}




\section{SLA Level of Women Trader}

Level of Sustainable Livelihood Approach (SLA) at Lok Baintan Floating Market is presented as in Table 11 and Figure 1. Table 11 and Figure 2 explain that physical asset has the highest level, that is $73.33 \%$. The second ones are human resources assets, natural resources assets, and social assets. The financial asset was the lowest level, which is $50 \%$.

Table 11. Level of SLA in Lok Baintan Floating Market

\begin{tabular}{lc}
\hline \multicolumn{1}{c}{ Aspect of SLA } & Value (\%) \\
\hline Natural resources assets & 57.33 \\
Financial assets & 50.00 \\
Human resources assets & 72.67 \\
Social assets & 53.33 \\
Physical assets & 73.33 \\
\hline & \\
&
\end{tabular}

Figure 1. Level of SLA in Lok Baintan Floating Market
Factors to Determine the Livelihood of Female Traders in Lok Baintan Floating Market

Factors in the level of community livelihood were analyzed using the Principal Component Analysis (PCA) method at seven assets, including natural resources, financial, human resources, social, physical, access, and activity. Access has correlated to less than 0.5 (0.373) (Table 12). Every trader has almost the same access capabilities as other traders. The access factor is excluded from the calculation due to the correlation value of less than 0.5 .

The number of factors formed in the percentage of variance column (Table 13). There are two factors formed, i.e. factor 1 with a value of 40.778 and factor 2 of 21.998. Both will determine the most influence factors to livelihoods of women traders in the Lok Baintan floating market. The influences of factor 1 and factor 2 are $62.778 \%$. Variables formed as factors include natural resources, financial, human resources, social, physical, and activity.

The variables that influence the livelihood level of female traders in Lok Baintan Village in group 1 are a natural resource, financial, and human with a correlation value of $0.944,0.936$, and 0.616 (Table 14). The second factor is physic, activity, and social with a correlation value of $0.787,0.626$, and 0.576 .

Table 12. Anti-image Matrices

\begin{tabular}{llrrrrrrr}
\hline & & Natural & Financial & Human & Social & Physic & Access & Activity \\
\hline Anti-image Covariance & Natural & .070 & -.066 & -.026 & .009 & .000 & -.075 & -.005 \\
& Financial & -.066 & .069 & .001 & -.024 & -.004 & .085 & .013 \\
& Human & -.026 & .001 & .772 & -.142 & .073 & -.109 & -.016 \\
& Social & .009 & -.024 & -.142 & .755 & -.205 & -.110 & -.021 \\
& Physic & .000 & -.004 & .073 & -.205 & .788 & -.202 & -.141 \\
& Access & -.075 & .085 & -.109 & -.110 & -.202 & .721 & -.002 \\
& Activity & -.005 & .013 & -.016 & -.021 & -.141 & -.002 & .953 \\
\hline Anti-image Correlation & Natural & $.536^{\mathrm{a}}$ & -.954 & -.113 & .038 & .001 & -.333 & -.021 \\
& Financial & -.954 & $.522^{\mathrm{a}}$ & .005 & -.104 & -.019 & .380 & .052 \\
& Human & -.113 & .005 & $.850^{\mathrm{a}}$ & -.186 & .094 & -.147 & -.019 \\
& Social & .038 & -.104 & -.186 & $.763^{\mathrm{a}}$ & -.266 & -.149 & -.025 \\
& Physic & .001 & -.019 & .094 & -.266 & $.611^{\mathrm{a}}$ & -.268 & -.162 \\
& Access & -.333 & .380 & -.147 & -.149 & -.268 & $.373^{\mathrm{a}}$ & -.002 \\
& Activity & -.021 & .052 & -.019 & -.025 & -.162 & -.002 & $.662^{\mathrm{a}}$ \\
\hline
\end{tabular}

a. Measures of Sampling Adequacy(MSA)

Table 13. Total Variance Explained

\begin{tabular}{|c|c|c|c|c|c|c|c|c|c|}
\hline \multirow[b]{2}{*}{ Component } & \multicolumn{3}{|c|}{ Initial Eigen values } & \multicolumn{3}{|c|}{ Extraction Sums of Squared Loadings } & \multicolumn{3}{|c|}{ Rotation Sums of Squared Loadings } \\
\hline & Total & $\begin{array}{c}\% \text { of } \\
\text { Variance }\end{array}$ & $\begin{array}{c}\text { Cumulative } \\
\% \\
\end{array}$ & Total & $\begin{array}{c}\% \text { of } \\
\text { Variance }\end{array}$ & Cumulative \% & Total & $\begin{array}{c}\% \text { of } \\
\text { Variance }\end{array}$ & $\begin{array}{c}\text { Cumulative } \\
\%\end{array}$ \\
\hline 1 & 2.447 & 40.778 & 40.778 & 2.447 & 40.778 & 40.778 & 2.402 & 40.035 & 40.035 \\
\hline 2 & 1.320 & 21.998 & 62.776 & 1.320 & 21.998 & 62.776 & 1.364 & 22.741 & 62.776 \\
\hline 3 & .858 & 14.293 & 77.069 & & & & & & \\
\hline 4 & .768 & 12.795 & 89.864 & & & & & & \\
\hline 5 & .567 & 9.456 & 99.319 & & & & & & \\
\hline 6 & .041 & .681 & 100.000 & & & & & & \\
\hline
\end{tabular}

Extraction Method: Principal Component Analysis. 
Table 14. Rotated Component Matrix ${ }^{a}$

\begin{tabular}{lcr}
\hline \multirow{1}{*}{ Aspects } & \multicolumn{2}{c}{ Component } \\
\cline { 2 - 3 } Natural & $\mathbf{1}$ & $\mathbf{2}$ \\
\hline Financial & .944 & -.036 \\
Human & .936 & -.070 \\
Social & .616 & .128 \\
Physic & .465 & .576 \\
Activity & .103 & .787 \\
\hline
\end{tabular}

Extraction Method: Principal Component Analysis.

Rotation Method: Varimax with Kaiser Normalization.

a. Rotation converged in 3 iterations

Physical assets are the highest assets that determine people's livelihoods based on the SLA level. The existence of water resources facilities, shelter, toilets, motorbikes, electricity, and information technology have been able to support the livelihoods of the women in Lok Baintan.

Human resource assets are assets that are high in determining people's livelihoods. Education, their children's education scholarship, their expertise, status in work, and assistance from their family members for working at Lok Baintan have been able to support their livelihoods.

Natural resource assets include a low score based on SLA levels. Ownership of water resources, land, agricultural land, plantation land, farmland, and livestock does not support people's livelihoods.

Social assets have a low score based on the SLA level. Social assets can increase the efficiency of economic relations and have an impact on increasing income. The way that can be done to strengthen social assets is by empowering groups/organizations, improving group functions through leadership and management capabilities. Strengthening social assets is by increasing networks with outside parties [20]. Empowering women in tourism organizations and increasing the role of women in these communities will strengthen social assets.

Financial assets have the lowest score based on the SLA level. Tourism activities have not been able to improve the economy of women traders in Lok Baintan due to the low income. The women only get the income between IDR 20.000 - 50.000 per day [2]. Financial assets have not been able to improve people's livelihoods in Lok Baintan.

Women in tourism do have a pretty good role, even though their role is still lower than that of men. Women have challenges in terms of education and training that are still lacking [21]. The factors that determine the role of women in tourism work are education, family background, physical condition, language, and the ability to set their own criteria [22]. According to reference [11], women should be given the opportunity to get tourism training and to have a responsibility in tourism activities. Women in tourism activities should not only be objects in tourism activities but also can determine policies in tourism activities.

\section{CONCLUSION}

The development of tourism in the Lok Baintan Floating Market is utilized by the community well. The traders' livelihood conditions are getting better with the floating market tourism area. It evidenced by seven livelihood assets that are in the moderate category. The results showed that the livelihoods of women traders are in the moderate category, meaning that natural resource assets, financial assets, human resource assets, physical assets, social assets, access, and activities are still able to support women's lives in tourist areas. Physical assets have the highest value of the sustainable livelihood approach (SLA) for 73.33\%. Financial assets have the lowest value of SLA, Which is $50 \%$. The influences of factor 1 and factor 2 were $62.778 \%$ for women trader livelihoods. Factors in group 1 were natural resource assets, financial assets, and human assets. The second factors were physical assets, activity, and social assets.

\section{Acknowledgments}

This research is funded by the Ministry of Research, Technology, and Higher Education through a research grant. The author would like to thank for the research funding.

\section{REFERENCES}

[1] Arisanty, D., E. Normelani, H. P. N. Putro, and M. Z. A. Anis. 2017. The role of women in Lok Baintan Floating Market, South Kalimantan: implication for tourism development. Journal of Indonesian Tourism and Development Studies 5(3), 169-174.

[2] Arisanty, D., E. Normelani, H. P. N. Putro, and M. Z. A. Anis. 2018. Local products of Lok Baintan Floating Market, South Kalimantan Province. IOP Conference Series: Earth and Environmental Science 145. DOI: 10.1088/ 1755-1315/145/1/012067.

[3] Arisanty, D., E. Normelani, H. P. N. Putro, and M. Z. A. Anis. 2019. The role of local government for local product processing: the implication for tourism sustainability in Lok Baintan Floating Market. Journal of 
Indonesian Tourism and Development Studies 7(1), 7-12.

[4] Kheiri, J. and B. Nasihatkon. 2016. The effects of rural tourism on sustainable livelihoods (case study: Lavij Rural, Iran). Modern Applied Science 10(10), 10-22.

[5] Shen, F. 2009. Tourism and the sustainable livelihoods approach: application within the Chinese context. Doctor of Philosophy. Lincoln University. New Zealand.

[6] Mugizi, F., J. Ayorekire, and J. Obua. 2018. Contribution of tourism to rural community livelihoods in the Murchison Falls Conservation Area, Uganda. African Journal of Hospitality, Tourism and Leisure 7(1), 117.

[7] Abdul, W. S. 1997. Analisis kebijakan dari formulasi ke implementasi kebijakan negara. PT Bumi Aksara. Jakarta.

[8] Ernawati, N. M. 2010. Tingkat kesiapan desa Tihingan-Klungkung, Bali sebagai tempat wisata berbasis masyarakat. Jurnal Analisis Pariwisata 10(1), 1-8.

[9] Afandi, A., C. F. Ananda, G. Maskie, M. Khusaini. 2014. Analysis of sustainable tourism livelihoods in Batu (East Java, Indonesia): SLFT approach (Sustainable Livelihood Framework for Tourism). Journal of Economics and Sustainable Development 5(10), 148-156.

[10] Parmawati, R., Soemarno, I. Nugroho, and B. Setiawan. 2012. Level of sustainable livelihood approach at Central Agriculture City of Batu. Journal of Basic Applied Scientific Research 2(6), 5631-5635.

[11] The World Bank Group. 2017. Tourism for development, women and tourism: designing for in inclusion. World Bank. Washington DC.

[12] ljeomah, H. M. A. 2012. Impact of tourism on livelihood of communities adjoining ecodestinations in Plateau State, Nigeria. Sustainability, Tourism and Environment in the Shift of a Millennium: a Peripheral View 6(3), 55-71.

[13] DFID. 2001. Sustainable livelihoods guidance sheets. Department for International Development. UK.

[14] Krantz, L. 2001. The sustainable livelihood approach to Poverty Reduction. Swedish International Development Cooperation Agency Division for Policy And SocioEconomic Analysis (SIDA). Swedish.

[15] Apriyanti, Y. and Partini. 2013. Strategi berdagang di pasar terapung Lok Baintan (studi kasus perempuan pedagang di Pasar Terapung Lok Baintan, Desa Lok Baintan, Kecamatan Sungai Tabuk, Kabupaten Banjar, Kalimantan Selatan). Master Thesis. Program Study of Sociology. Gadjah Mada University.

[16] Ellis, F. 2000. Rural livelihoods and diversity in developing countries. Oxford University Press Inc. New York.

[17] Parmawati, R., Soemarno, Maryunani, A. S. Kurnianto. 2018. Analysis of poverty in forest surrounding communities by sustainable livelihood approach. Jurnal Antropologi: IsuIsu Sosial Budaya 20(1), 1-15.

[18] Smith, L. I. 2002. A tutorial on Principal Components Analysis. Available at: http://www.cs.otago.ac.nz/cosc453/student _tutorials/principal_components.pdf.

[19] Ifadah, A. 2011. Analisis metode Principal Component Analysis (komponen utama) dan Regresi Ridge dalam mengatasi dampak multikolinearitas dalam analisis regresi linear berganda. Thesis. Department of Mathematics. State University of Semarang.

[20] Oktalina, S. N., S. A. Awang, S. Hartono, P. Suryanto. 2016. The farmer livelihood asset mapping on community forest management in Gunungkidul District. Jurnal Manusia dan Lingkungan 23(1), 58-65.

[21] Deen, A., V. Harilal, F. N. Achu. 2016. Women in tourism: experiences and challenges faced by owners of small accommodation establishments. African Journal of Hospitality, Tourism and Leisure, Special Edition 5(3), 1-15.

[22] Sony, K. C. 2012. Roles and challenges of women in tourism sector of Western Nepal: a micro- ethnographic study. Nepal Tourism and Development Review 2, 32-59. 